\title{
lodine content of dietary salt at household level and associated factors using lodometric titration methods in Dera District, Northwest Ethiopia
}

\author{
Zelalem Alamrew Anteneh ${ }^{1 *}$ (D) Melese Engidayehu ${ }^{2}$ and Gedefaw Abeje
}

\begin{abstract}
Background: In developing countries most of the edible salts have insufficient iodine content; the problem is worse in Africa. Only $15.4 \%$ of the Ethiopian population was using adequately iodized salt. Several factors affect iodine content of edible salt including poor handling practices. The existing evidence isn't sufficient to detail the specific factors at the household level. Therefore, the aim of this study was to determine the iodine content of edible salt and identify factors associated with salt iodine content in Dera District, Northwest Ethiopia.

Methods: A community-based cross-sectional study was conducted among 1194 households. A multi-stage sampling technique was used to select the households, and data were collected using the interview. A $50 \mathrm{~g}$ salt sample was collected from each selected household and was shipped to the Ethiopian Food, Medicine and Health Care administration and Control Authority (EFMHACA) laboratory center for iodine level analysis. The samples were analyzed using titration method. Data were entered into EPI-INFO and analyzed in SPSS.

Results: Out of 1194 salt samples collected, 57.4\% had iodine content in the range 15 ppm to $59.42 \mathrm{ppm}$. Salt stored in closed containers was more likely to have better iodine content compared to salt stored with open containers (AOR $=1.7,95 \% \mathrm{Cl}: 1.24-2.42)$. Salt samples stored in dry places were 1.5 times more likely to retain iodine compared to samples stored near to heat/fire or in a moist area (AOR $=1.5,95 \% \mathrm{Cl}: 1.03-2.14$ ). Similarly, salt samples stored for less than 2 months were more likely to have adequate iodine level compared to samples stored for over 2 months ( $A O R=$ $1.6,95 \%$ Cl: 1.12-2.29).

Salt samples obtained from household heads attended primary education ( $A O R=1.5,95 \%$ Cl: 1.05-2.26), high school $(\mathrm{AOR}=1.7,95 \% \mathrm{Cl}: 1.05-2.64)$, and University ( $\mathrm{AOR}=2.8,95 \% \mathrm{Cl}: 1.06-5.62)$ were more likely to have adequate iodine content in edible salt compared to whose didn't attend formal education.

Conclusions: Nearly three out of five salt samples had enough iodine content. However, this level is low compared to the WHO recommendation (90\%). The age, educational status of head of the household, duration of salt storage, use of cover to store salt and knowledge of household heads were associated with an iodine content of salt. Therefore, use of cover and proper storage of edible salt should be encouraged; improving the educational status of the community is essential the edible salt to retain its iodine content at the household level.
\end{abstract}

Keywords: Iodine content, Ethiopia, Titration method

\footnotetext{
* Correspondence: kzolam@gmail.com

${ }^{1}$ School Public Health, College of Medicine and Health Sciences, Bahir Dar

University, Bahir Dar, Ethiopia

Full list of author information is available at the end of the article
} 


\section{Background}

Iodine is an essential micronutrient for humans required in a very small amount $[1,2]$. The daily recommended amount of iodine for normal function of thyroid gland is $150-200 \mu \mathrm{g} / \mathrm{l}$ for adults, $90-120 \mu \mathrm{g} / \mathrm{l}$ for children and $250 \mu \mathrm{g} / \mathrm{l}$ for pregnant \& lactating mothers [3-5]. World health organization (WHO) recommends that the median iodine urinary level need to be within the range $(100-199 \mu \mathrm{g} / \mathrm{l})$ to ensure adequate iodine content in salt and other sources of iodine in the diet. Or iodized salt containing 15 to $40 \mathrm{ppm}$ of iodine at the household level regarded as adequately iodized [6].

Iodization of salt is first line measure to prevent and control iodine deficiency disorders. The Ethiopian Council of Ministers passed salt legislation in February 2011; according to this regulation, every salt for human consumption need to be iodized, and any iodized salt for human consumption shall conform to the standards for iodized salt set by the appropriate authorit [7].

Iodine Deficiency (ID) is the most common preventable cause of intellectual impairment. Globally, 241 million population are estimated to have insufficient iodine intakes. The problem is worse in Southeast Asia and Africa, where 76 million and 58 million populations have inadequate iodine intake respectively [8]. According to the Ethiopian National Nutrient survey report, $47.5 \%$ of school children had urinary iodine levels less than $100 \mu \mathrm{g} / \mathrm{L}$. The median Urinary iodine level in nonpregnant women of reproductive age was $96.8 \mu \mathrm{g} / \mathrm{L}$; about $51.8 \%$ of women had urinary iodine levels less than $100 \mu \mathrm{g} / \mathrm{L}$. The report also showed that only $26 \%$ of the total households were getting more than $15 \mathrm{ppm}$ iodine in salt [9]. Similarly, Ethiopian Demographic and Health Survey (EDHS) 2011 indecated that about 66 million persons were unprotected from iodine deficiency, and only $15 \%$ of households had access to iodized salt [10].

A study in Sudan showed that $85.6 \%$ of the population obtained $13.7 \mathrm{mg}$ of iodine in salt [11]. In Ghana, 5\% of the population consumes salt without iodine and 19.4\% of the population consumes below the country's recommended level [12]. Another study in Haiti showed that among salt samples tested for iodine content, $86 \%$ of the table salts labeled as "iodized" were found with no iodine at all [13]. A similar study conducted in India showed that out of the total salt samples collected, $13.2 \%$ had zero $\mathrm{mg}, 4.1 \% 1-5 \mathrm{mg}$ and $17.4 \%$ 6-15 $\mathrm{mg}$ of iodine per $1 \mathrm{~kg}$ of salt [14].

A study conducted in Benishagul Gumze region, western Ethiopia, pointed out that $27.0 \%$ and $52.9 \%$ of the households were consuming salt with zero, and between zero to $15 \mathrm{ppm}$ iodine content respectively [15]. And a study done in Hawassa town, Ethiopia showed that all salt samples tested for iodine had iodine concentration below the recommended level [16]. Another study done in Laelay Maychew district, Northern Ethiopia showed that $19.2 \%$ and $38 \%$ of the households were consuming salt with zero, and less than $15 \mathrm{mg} / \mathrm{kg}$ of iodine content [17]. A similar study conducted in Lay Armachiho rural district showed that $37.5 \%$ of salt samples reported no iodine in it and $32.8 \%$ contained $1-15 \mathrm{mg}$ iodine per $\mathrm{kg}$ of salt [18].

Improper storage, poor handling practices and buying non iodized salt are some of the cause for low iodine content in salt [19-21]. Studies showed that there are several causes for low iodine content of edible salt at household level; a study conducted in India showed that iodine content in salt was reduced due to personal and environmental causes from its production site to the consumer level [22].

In Ghana, salt handling practice was the main cause for loss of iodine content in salt [12].

A study conducted in Southern Ethiopia identified age, education level, poor knowledge and poor handling practices as important predictors of iodine content of edible salt of households [16].

Although Ethiopia is enforcening the universal salt legislation to increase the content of iodine in edible salt, there is a limited evidence on the level of iodine content of salt and factors that affect its content at household level. Therefore, this study was designed to determine the iodine content of salt and identify factors associated with its content in households in Dera district.

\section{Methods}

\section{Study design and period}

A community-based cross-sectional study was done in December 2015.The study performed in South Gondar zone Dera district, found between 1500 and $1800 \mathrm{~m}$ above sea level, $612 \mathrm{kms}$ from Addis Ababa (the capital of Ethiopia) in the Northwest and $42 \mathrm{kms}$ from Bahir-Dar (the capital city of Amhara region).

The district comprises 32 kebeles (the smallest administrative units in Ethiopia), 87\% of the population living in the distrct have access to health care; there were 10 health centers and 36 health posts in the district.

\section{Study population and variables}

All households of Dera district living in the selected kebeles were eligible for the study. Households and individuals in the household who were responsible (the woman) in food preparation were the study units.

\section{Sample size and sampling procedures}

A single population proportion formula used using EPINFO. The following assumptions were used: 95\% confidence interval, assuming that $36.3 \%$ of salt samples is adequately iodized, $80 \%$ power, 1.61 odds ratio, $5 \%$ margin 
of error. Adding 10\% non-response rate and using design effect of 2 the final sample size was 1241.

Multistage sampling procedure was used. From the total of 32 kebeles in the District, five were selected randomly. The calculated sample size was allocated into the selected Kebeles based on the number of households they had. Households were selected using systematic sampling strategy. The salt samples were collected in each household and were analyzed in the Amhara region FMHACA laboratory and the concentration of iodine was measured in titration method. In this study, the salt collected from the households was considered adequately iodized if the iodine level in the salt is from 15 to $40 \mathrm{mg}$ of iodine per $\mathrm{kg}$ of salt [6].

\section{Data collection procedures}

Data were collected using interview administrated questionnaire. The questionnaire was adapted from reviewed literature [16-18, 23] (Additional file 1). The data were collected by 11 data collectors who had similar data collection experiences in the rural community. Two days training was given to data collectors on the purpose of the study, data collection techniques, and on ethical issues in research. They were also trained on how to collect the salt samples. A pretest was conducted in Zenzelima Kebele (rural kebele of Bahir Dar city administration), which was not included the main study. Necessary changes were made to the questionnaire before the actual data collection. A $50 \mathrm{~g}$ salt sample was collected carefully from the selected households with an airtight plastic bag.

An information sheet with the date of sample collection, code of the sample, and type of salt, packing material, batch number if, date of production, expiry date, name and signature of data collector was attached to the salt sample. Salt samples were packed and sent from the data collectors to the supervisors daily. The supervisors sent the salt samples to the investigators the next day to the laboratory (North-west branch of EFMHACA) in Bahir Dar city (where titration analysis was done). There are different tests to assess the level of iodine in salt. In this study, we used the titrimetric titration method which is $85.4 \%$ sensitive and $71.25 \%$ specific to detect the level of iodine in salt. The equipments needed, the chemical and test procedures are annexed (Additional file 2).

\section{Data analysis}

The collected data were checked for errors and completeness on daily basis. Data were entered into EPI- Info version 7 and exported to SPSS version 20 for analysis.

Frequencies and percentages were done to see the magnitude of events in the study. Bivariate logistic regression analysis was computed to test whether there is an association between Iodine content of salt and selected independent variables.

Independent variables with a significance level less than or equal to 0.20 in the bivariate logistic regression analysis were entered to the multivariable logistic regression analysis. The multivariable logistic regression model was built with backward elimination.

\section{Results}

\section{Socio-demographic characteristics}

Data were collected from 1194 households (96.2\% response rate). The mean and standard deviation of the age of respondents was $35.19 \pm 12.67$ years. The majorities $(90 \%)$ of the respondents were females.

Two hundred and fifty (20.9\%) respondents could not read and write, and 358 (30\%) engaged in adult education. Most respondents (97.8\%) were Amhara in Ethnicity, and 1047 (87.7\%) were Orthodox Christians in religion (Table 1).

Table 1 Socio-demographic characteristics of respondents in Dera District, North West Ethiopia, Dec 2015

\begin{tabular}{|c|c|c|}
\hline Variables $(N=1194)$ & Frequency & Percent \\
\hline \multicolumn{3}{|l|}{ Age of the respondent } \\
\hline $18-29$ years & 507 & 42.5 \\
\hline 30-44 years & 391 & 32.7 \\
\hline$\geq 45$ years & 296 & 24.8 \\
\hline \multicolumn{3}{|l|}{ Wealth Index } \\
\hline Poor & 395 & 33.3 \\
\hline Medium & 401 & 33.6 \\
\hline Rich & 398 & 33.1 \\
\hline \multicolumn{3}{|c|}{ Occupation of the respondent } \\
\hline Housewife & 942 & 78.9 \\
\hline Government employee & 60 & 2.7 \\
\hline Merchant & 89 & 7.5 \\
\hline Daily Laborer & 32 & 2.7 \\
\hline Others (Beggars) & 25 & 2.1 \\
\hline \multicolumn{3}{|l|}{ Family Size } \\
\hline$<5$ & 1046 & 87.6 \\
\hline 5 or more & 148 & 12.4 \\
\hline \multicolumn{3}{|l|}{ Marital Status } \\
\hline Married & 785 & 65.7 \\
\hline Single & 218 & 18.3 \\
\hline Divorced & 112 & 9.4 \\
\hline Separate & 15 & 1.3 \\
\hline Widowed & 64 & 5.4 \\
\hline
\end{tabular}


lodine content and handling practices of edble salt at household level in Dera District

In this study, iodine content of edible salt varied from 0.00 to $59.42 \mathrm{ppm}$ (ppm) with a mean and standard deviation of 20.79 and $11.56 \mathrm{ppm}$ respectively. Out of the total salt samples tested for iodine content, 685 (57.4\%) had acceptable iodine content between (15-59.42 ppm) based on the WHOs cut of points. However, 44 (3.6\%) salt samples had no Iodine at all, and the remaining $40.6 \%$ salt samples contained less than $15 \mathrm{mg}$ of iodine $/ \mathrm{kg}$ of salt.

Regarding the salt the households use, $87.51 \%$ used the crystal form and the rest were using powdered and packed. Out of the total salt samples with adequate iodine content, the majority $71.8 \%$ were in crystal form (See Fig. 1).

About 376 (31.5\%) respondents reported that they used iodized salt properly; 453 (37.9\%) of them used for about 2-4 years. Five hundred and fifty (46.1\%) households reported that iodized salt is accessible for them to buy within a reasonable distance.

In addition, 1003(84\%) of the households bought their iodized salt from their usual market, the only handful of them bought from village shops.

Seven hundred and ninety-seven (66.8\%) of households place their salt in the covered container. When tested for iodine content, $77.5 \%$ of the salt samples from this household were found adequately iodized.

Of the total study households, 939 (78.6\%) reported that they store their salt in a dry area, $86.1 \%$ of salt samples obtained from these households were found adequately iodized. Similarly, 997 (83.5\%) of the households reported that they stored their salt for less than 2 months. Among those who store salt for less than 2 months, $89.6 \%$ of salt samples were adequately iodized (See Table 2).
Table 2 lodine content of edible salt and handling practices in Dera District, North West Ethiopia, Dec-2015

\begin{tabular}{|c|c|c|}
\hline Variables & Frequency & percent \\
\hline \multicolumn{3}{|l|}{ Salt buy from } \\
\hline Usual market & 1003 & 84 \\
\hline Village shop & 191 & 16 \\
\hline \multicolumn{3}{|l|}{ Type of salt used } \\
\hline Crystal & 1045 & 87.51 \\
\hline Powder & 149 & 12.49 \\
\hline \multicolumn{3}{|c|}{ Salt leveling observable by data collector } \\
\hline Yes & 137 & 11.5 \\
\hline No & 1057 & 88.5 \\
\hline \multicolumn{3}{|l|}{ Salt storage place } \\
\hline Dry & 939 & 78.6 \\
\hline Moist area & 254 & 21.4 \\
\hline \multicolumn{3}{|c|}{ Storage or storage time in house } \\
\hline$<2$ months & 997 & 83.5 \\
\hline 2 or more months & 197 & 16.7 \\
\hline \multicolumn{3}{|c|}{ Salt exposed to sun/heat } \\
\hline Yes & 28 & 2.3 \\
\hline No & 1166 & 97.3 \\
\hline \multicolumn{3}{|l|}{ lodine content in salt } \\
\hline$\geq 15 \mathrm{ppm}$ & 683 & 57.4 \\
\hline$<15$ ppm & 511 & 42.6 \\
\hline
\end{tabular}

\section{Factors associated with edible salt iodine content}

According to the multivariable logistic regression analysis, salt samples from respondents aged 18 to 29 and 30 to 44 years were more likely to have adequate iodine level compared to those whose age was above 45 years $(\mathrm{AOR}=2.2,95 \% \mathrm{CI}: 1.60-3.13)$ and $(\mathrm{AOR}=2.2$,

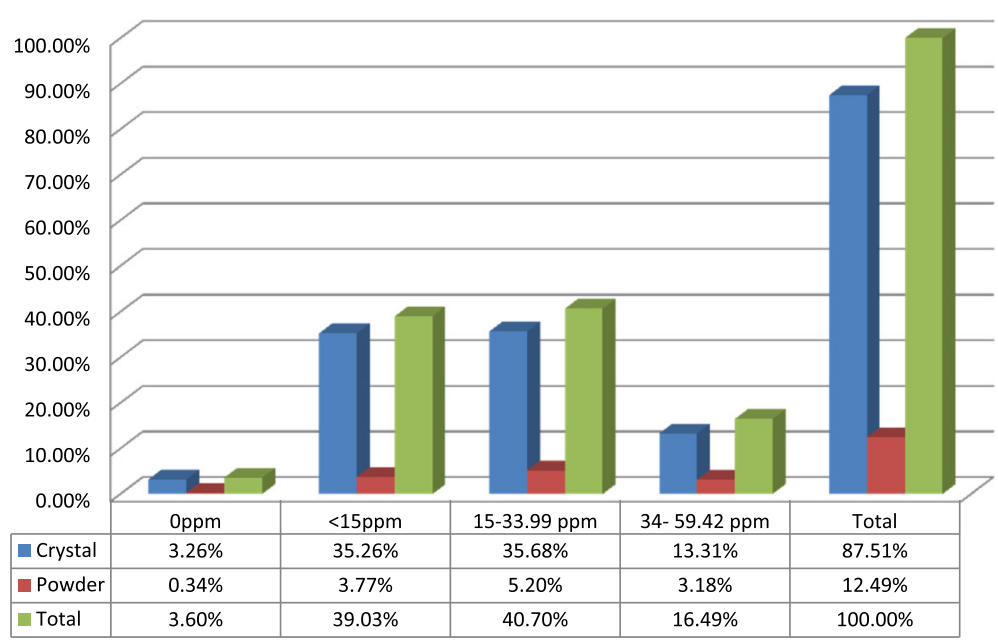

Fig. 1 The lodine contents in the crystal and powder forms of salt in Dera District, Northwest Ethiopia, Dec. 2015 
95\% CI: 1.6-3.16) respectively. Salt samples from households who stored salt in a closed containers were 1.7 times more likely to have adequate iodine content compared to salt samples obtained from households who stored in an open containers (AOR $=1.7,95 \% \mathrm{CI}$ : 1.24-2.42). The study also showed that salt samples from households who store salt in dry place were 1.5 times more likely to have adequate iodine content compared to households who place salt in moist area $(\mathrm{AOR}=1.5$, 95\% CI: 1.03-2.14).

Similarly, salt samples taken from households who stored salt for less than 2 months were 1.6 times more likely to have adequate iodine content compared to those salt samples taken from households who stored for over 2 months (AOR $=1.6,95 \%$ CI: 1.12-2.29) (See Table 3).

\section{Discussions}

The aim of this study was to find out the iodine content of edible salt at household level and the factors that may affect iodine content of edible salt in the rural community of Dera district. The study identified that three out of five (57.4\%) salt samples had acceptable iodine content based on the $\mathrm{WHO}$ recommended level. According to the $\mathrm{WHO}$ and
International Council for Control of Iodine Deficiency (ICCIDD) standard, elimination of Iodine Deficiency Disease (IDD) will be possible if over $90 \%$ of the households consume adequately iodized salt [24].

The percentages of edible salt with acceptable iodine at household level in this study was higher than a similar study conducted in 2014 in the Northwest region of Ethiopia [18].

Similarly, our finding was higher than studies conducted in Kenya in 2015 26.2\% [25], and in Senegal 10\% [26], Sudan 14.4\% [11] and Haiti 11\% [13] in 2012.

The possible reason for higher proportion of iodine content in our study may be because Ethiopia has made a major effort to stimulate and improve iodine status under the national salt iodization strategy for the last few years. The government of Ethiopia dedicated group ministry of health (FMHACA) to work up on iodization and other essential activities in health; the ministry then has banned sale of non-iodized salt for direct human consumption throughout the country in 2012 [27]. In addition, this study was undertaken after the Ethiopian government enforces salt legislation for mandatory salt iodization which was ratified and approved by Council of Ministers. Regular follow up and monitoring might

Table 3 Factors associated with iodine content in salt at household level in Dera district, Dec 2015

\begin{tabular}{|c|c|c|c|c|}
\hline \multirow[t]{2}{*}{ Variables } & \multicolumn{2}{|c|}{ lodine content } & \multirow[t]{2}{*}{ COR $(95 \% \mathrm{Cl})$} & \multirow[t]{2}{*}{ AOR $(95 \% \mathrm{Cl})$} \\
\hline & $<15 \mathrm{ppm}$ & $\geq 15 \mathrm{ppm}$ & & \\
\hline \multicolumn{5}{|l|}{ Age of respondents } \\
\hline $18-29$ & 180 & 341 & $3.3(2.47-4.53)$ & $2.2(1.60-3.13)$ \\
\hline $30-44$ & 151 & 240 & $2.8(2.04-3.85)$ & $2.2(1.60-3.16)$ \\
\hline $45 \&$ above & 180 & 102 & 1 & 1 \\
\hline \multicolumn{5}{|l|}{ Storage time in house } \\
\hline$<2$ months & 383 & 614 & $3.0(2.16-4.01)$ & 1.6(1.12-2.29) \\
\hline 2 and above months & 128 & 69 & 1 & 1 \\
\hline \multicolumn{5}{|l|}{ Educational of respondents } \\
\hline Unable to read \& write & 155 & 95 & 1 & 1 \\
\hline Able read \& Write & 168 & 190 & $2(1.43-2.76)$ & $1.28(0.89-1.84)$ \\
\hline Primary & 114 & 216 & $3.1(2.22-4.40)$ & $1.5(1.05-2.26)$ \\
\hline Secondary & 56 & 134 & $4.0(2.68-6.00)$ & $1.7(1.06-2.64)$ \\
\hline Higher & 16 & 50 & 7(3.62-13.50) & $2.8(1.39-5.62)$ \\
\hline \multicolumn{5}{|l|}{ Use Cover for their salt } \\
\hline Yes & 266 & 531 & $3.2(2.45-4.04)$ & $1.7(1.24-2.31)$ \\
\hline No & 243 & 154 & 1 & 1 \\
\hline \multicolumn{5}{|l|}{ Salt Storage Place } \\
\hline Dry Area & 350 & 589 & $3.4(2.63-4.34)$ & $1.5(1.03-2.14)$ \\
\hline Near Heat/fire area & 161 & 94 & 1 & 1 \\
\hline \multicolumn{5}{|l|}{ Knowledge respondents } \\
\hline Good Knowledge & 362 & 564 & $2(1.48-2.57)$ & $1.7(1.27-2.31)$ \\
\hline Poor knowledge & 149 & 119 & 1 & 1 \\
\hline
\end{tabular}


cause awareness and the rate of salt iodization may be increased; this might raised availability \& accessibility of iodized salt at household level. However, the proportion of households with adequate iodine content in salt in this study was lower compared to studies conducted in Nigeria 95\% [28], Ghana $75.6 \%$ [12] India and Tajikistan(64\%, 71\% respectively) $[29,30]$.

The possible reason for this discrepancy may be the difference in technology and institutional factors to refine iodize salt, lack of enforcement in the legislation, and quality-controlled iodization technology at the production site, awareness of community, effective transport channels, correct labeling, packaging and storage.

This study identified that 44 (3.6\%) of salt samples didn't contain iodine at all; which entails people consumed salt without iodine. Similar findings were observed in studies conducted in Ghana (5\%) and India (13.2\%) in 2012 where the salt samples were found with zero iodine content at household level [31, 32]. However, the results of the current study are much better than studies conducted in Lay Armachiho and Benishagulgumze in Ethiopia by 2014, where the percentages of zero level iodine content in edible salt were $23.5 \%$ and $27 \%$ respectively $[15,18]$.

Age of respondents was significant predictors of iodine content of salt. Respondents of younger age ( $<44$ years) were more than two times more likely have had adequately iodized salt at home compared to those 45 and older. This finding was consistent with studies in Gondar [23] and Kenya [25] where salt samples collected from young aged respondents were more likely to contain an adequate level of iodine in salt than samples collected from respondents of older age. This might be linked to the exposure to different social media and other information sources on iodized salt. As age advances exposure to different media likely to decrease.

Educational level of respondents was associated with the availability of adequately iodized salt in the household. A similar finding was found in study conducted in Kenya, where the educational status of the respondent was associated with an adequate level of iodine in edible salt in the household [25].

The findings of the current study also identified that the storage place of iodized salt was an important factor for the availability of adequately iodized salt in the household. Storing edible salt in dry and enclosed containers at household level helps the salt to retain its iodine content. Our finding was supported by other similar studies conducted in Gondar and Lay Armachiho district [17, 23], where availability of adequately iodized salt were high in those storing their salt in dry area and closed containers than those storing their salt near fire/heat or in moist area and open containers. This may be due to the fact that if salt stored in humid condition and stay for longer period, it attracts moisture and becomes wet, carrying the iodide part to the bottom of the container. At hot condition, salt can release surface moisture, and this may cause an iodine loss by its volatility if the container is opened. This study identified the level of iodine in salt at households only. However, salt may lose its iodine content at production, transport and storage sites. Therefore, this study fails to show the specific situation where iodine content of the salt is lost.

\section{Conclusions}

The availability of adequately iodized salt at household level in the district is lower than the WHO recommended level.

We also found out that age and educational status of the household heads, salt storage time, and storage area were associated with the presence of adequately iodized salt at household level.

Therefore, education should be promoted. Concerned organizations including the regional education bureau should encourage women's education to improve iodine content of salt at household level.

We encourage the households to put their iodized salt in dry place in a closed container to preserve the iodine content of the salt. What is more, we discourage to store iodized salt more than 2 months, as the salt loses its iodine content.

Finally, further study is needed to identify the place of iodine loss from the salt; is it at place of manufacture, during transport or in the shop.

\section{Additional files}

Additional file 1: The English Version Questionnaires. (DOCX $30 \mathrm{~kb}$ )

Additional file 2: Equipment, chemicals used and procedures followed. (DOCX $22 \mathrm{~kb}$ )

\section{Acknowledgements}

We would like to thank Bahir Dar University for providing us ethical clearance to conduct the study. Our heartfelt thanks goes to our data collectors, supervisors and the study community.

\section{Funding}

This study was funded with the authors' own contributions.

Availability of data and materials

The data that supported the findings of this study are available from the corresponding author on request.

\section{Authors' contributions}

ZAA and GA designed the study, performed analysis, and involved in interpretation of the data and critically reviewed the manuscript. ME conceived and designed the study, performed analysis, interprated the data and drafted the manuscript. All authors read and approved the final manuscript. 


\section{Ethics approval and consent to participate}

The purpose and aims of the study were explained to the study participants. Verbal consent was received from each respondent. Participation was voluntarly. Information obtained from the study participants was kept confidential by using codes for each household and keeping the document in secure place. Ethical clearance was obtained from Bahr Dar University Ethical Review committee; and permission letters were received from Amhara national regional health bureau, South Gondar Zonal Health Department, and Dera District Health Office.

\section{Consent for publication}

Not applicable.

\section{Competing interests}

The authors declare that they have no competing interest.

\section{Publisher's Note}

Springer Nature remains neutral with regard to jurisdictional claims in published maps and institutional affiliations.

\section{Author details}

${ }^{1}$ School Public Health, College of Medicine and Health Sciences, Bahir Dar University, Bahir Dar, Ethiopia. ${ }^{2}$ Health and health related logistics and institutions inspector, Ethiopian food, medicine and health care control authority, Northwest branch of Ethiopia, Bihar Dar, Ethiopia.

Received: 6 June 2017 Accepted: 15 November 2017 Published online: 28 November 2017

\section{References}

1. World Health Organization. Micronutrients. 2017 [cited 201718 May]; Available from: http://www.who.int/nutrition/topics/micronutrients/en/.

2. Center for Disease control and Prevention. International Micronutrient Malnutrition Prevention and Control (IMMPaCt). March 2015 [updated March 31, 2015; cited 201718 May]; Available from: https://www.cdc.gov/ immpact/micronutrients/.

3. International Council for control of lodine Deficency Disorders. Progress against widespreadiodine deficiency in Europe. In: IDD Newsletter; 2008

4. Naved Ahmad MP, Gupta A, Chandra P. Estimation of iodine content of edible salt in rural areas of Meerut District, Uttar Pradesh. Int J Health Sc Res. 2012;2(9):25-9.

5. World Health Organization. Prevention and control of iodine deficiency in pregnant andlactating women and in children less than 2-years-old: conclusions and recommendations of the technical consultation. Public Health Nutr. 2007;10(12A):1606-11.

6. World Health Organization, UNICEF, ICCIDD. Assessment of iodine deficiency disorders and monitoring their elimination; a guide for programme managers, Third edition (updated1st September 2008). Available from: http://www.who.int/nutrition/publications/micronutrients/iodine_deficiency/ 9789241595827/en/. Accessed 21 Nov 2017.

7. Ethiopian COUNCIL OF MINISTERS. Salt lodization Council of Ministers Regulation No. 20412011". Addis Ababa, Ethiopia2011 [cited 201720 July]; Available from: https://chilot.me/2011/11/22/salt-iodization-council-ofministers-regulation-no-20412011\%.

8. Maria Andersson VK, Zimmermann MB. Global iodine status in 2011 and trends over thePast decade. J Nutr. 2012;112:744-50.

9. Ethiopian Public Health Institute. National Micronutrient Survey Report Addis Ababa: Federal Ministry of Health, 2016 2016. Report No.

10. International. CSAEal. Ethiopia demographic and HealthSurvey 2011. Addis Ababa: Ethiopia Central Statistical Agency and ICF International; 2012.

11. ICCIDD, International Council for control of lodine Deficiency Disorders. Sudan launches universal salt iodization. In: IDD Newsletter; 2012.

12. Christiana BBB. Knowledge and practices of people in Bia District, Ghana, with regard to iodine deficiency disorders and intake of iodized salt. Arch Public Health. 2012;70(1):5.

13. Ngnie-Teta I, RF MAA, Mamadoultaibou A. lodine content in imported table salt in Haiti on the eve of a mandatory salt iodization bill. In: Idd Newsletter; 2012

14. MGKII KYC. Adequately iodized salt covered seventy-one percent of India international council for control of iodine deficiency disorders. 2011:39(2).

15. TWG. S. Cross-sectional survey of Goiter prevalence and household salt iodization levels in Assosa town, Beni Shangul-Gumuz region, West Ethiopia. J Pregnancy Child Health. 2014;(31000119)
16. Meron Girma EL, Alemtsehay Bogale et al, . lodine deficiency in primary school children and knowledgeof iodine deficiency and iodized salt among caretakers inHawassa town: southern Ethiopia Ethiopian journal of health development. 2012;26(1):30- 35.

17. Gidey BAK, Atnafu A, et al. Availability of adequate iodized salt at household level and associated factors in rural communities in Laelay Maychew District, northern Ethiopia. J Nutr Health Sci. 2015;2(1)

18. Molla Mesele GD, Gebrehiwot $H$. Prevalence and associated factors of goiter among rural children aged 6-12 years old in Northwest Ethiopia, cross -sectional study. BMC Public Health. 2014;14

19. Ethiopian Demographic and Health Survey. Assessment report of iodine status at HH level in Ethiopia. Addis Ababa: Central statistics agency; 2015.

20. Pieter LJM, Lombard CJ. Short-term effectiveness of mandatory iodization of table salt, at an elevated iodine concentration, on the iodine and goiter status of schoolchildren with endemic goiter. Am Soc Clin Nutr. 2015;71:75-80.

21. Pan American Health Organization. Improving Public Health in the Americas by Optimizing Sodium and lodine Intakes. 2011 [updated 05/17/2013 12:35; cited 201729 July]; Available from: http://www.paho.org/hq/index.php?option=com_ docman\&task=doc_details\&gid=21494\&ltemid=270\&lang=en.

22. Zimmermann M. lodine deficiency uncovered in the UK. In: The IDD Newsletter; 2011.

23. Gebrearegawi H, Gebremariam MDNK. Availability of adequately iodized salt at household level and associated factors in Gondar town, Northwest Ethiopia. Health ISRN Public. 2013;6(160582)

24. World Health Organization. Assessment of iodine deficiency disorders and monitoring their elimination: a guide for program managers health organization. 3rd ed; 2007.

25. Kahindi Kazungu CM, Anzelimo Makokha,. Factors contributing to iodine Deficeiency in Coast Province of Kenya. Eur J Res Med Sci. 2015; Vol. 3 ( 2056-600X).

26. Roland Kupka BN, Mamadou Guelaye Sall, Boubacar Camara, . Senegal struggles to control iodine deficiency. 2012.

27. EFMHACA. Regulatory standard setting and information dissemination Directoret. In: lodized salt directive Addis Ababa, Ethiopia; 2012.

28. Umenwanne EOAI. Inadequate salt iodization and poor knowledgeattitudes, and practices regarding iodine-defi ciency disorders in an area of endemic goitre in south-eastern. Nigeria Food Nutr Bull. 2010;21(3):311-5.

29. Yongning $\mathrm{Wu} X \mathrm{~L}$, Chang $\mathrm{S}$, et al. Variable iodine intake persists in the context of universal salt iodization in China. J Nutr. 2012;142(9):1228-734.

30. Barbara Matthys MD, Karimova G, et al. lodine nutritional status and risk factors for goitre among schoolchildren in South Tajikistan. BMC Endocr Disord. 2013;2(13)

31. Clement Ahiadeke CA, Aryeetey R, Acquah A. Factors influencing the use of adequately iodated salt in Ghana. Afr J Food Sci. 2012;6(3):58-64.

32. Karen Charlton HSA, Gemming L, et al. Poor knowledge and practices related to iodine nutrition during pregnancy and lactation in Australian women. Pre- and Post-lodine Fortification. 2012;4:1317-27.

\section{Submit your next manuscript to BioMed Central and we will help you at every step:}

- We accept pre-submission inquiries

- Our selector tool helps you to find the most relevant journal

- We provide round the clock customer support

- Convenient online submission

- Thorough peer review

- Inclusion in PubMed and all major indexing services

- Maximum visibility for your research

Submit your manuscript at www.biomedcentral.com/submit
) Biomed Central 